\title{
Impact of protein standardization of milk powder with lactose or permeate on whey protein nitrogen index and heat classification
}

\author{
Vandna SIKAND ${ }^{1}$, Phillip S. TONG ${ }^{2 *}$, John WALKER $^{3}$ \\ ${ }^{1}$ Dairy Products Technology Center, California Polytechnic State University, 1 Grand Avenue, \\ San Luis Obispo, CA, 93407, USA \\ ${ }^{2}$ Dairy Science Department, California Polytechnic State University, 1 Grand Avenue, \\ San Luis Obispo, CA, 93407, USA \\ ${ }^{3}$ Statistics Department, California Polytechnic State University, 1 Grand Avenue, \\ San Luis Obispo, CA, 93407, USA
}

\begin{abstract}
Whey protein nitrogen index (WPNI) is a well-known method of classifying nonfat dry milk powder (NFDM) based on its heat treatment. This classification scheme provides one criterion for the selection of NFDM for food applications. However, the effects of variation in NFDM composition on WPNI are not well documented. The objective of this study was to determine the effects of changing protein content in low heat and medium heat NFDM on WPNI value. Edible lactose powder (ELP) and permeate powder (PP) from skim milk ultrafiltration were used to downward standardize NFDM from a protein content of 35.5-30\% protein on a wet basis. These standardized powders were analyzed for WPNI by American Dairy Products Institute (ADPI) method. Powders were also analyzed for protein, ash, fat, moisture and lactose by standard methods to describe the composition. Using linear regression, WPNI was found to be positively associated with protein content for both low and medium heat NFDM from several suppliers. For example, a low heat NFDM (from supplier B) with initial protein content of 34.3\% (wet basis) and WPNI of $6.38 \mathrm{mg}$ soluble whey protein nitrogen (classified as a low heat powder) had its WPNI reduced to less than $6.0 \mathrm{mg}$ of soluble nitrogen per $\mathrm{g}$ of powder when standardized to a protein content of less than or equal to $31.89 \%$ (wet basis) with either ELP or PP. This would reclassify it as medium heat powder. We conclude that standardization of NFDM with lactose or permeate will change its WPNI value and may effect its heat classification. We propose a modified approach to calculate WPNI based upon soluble whey protein nitrogen per g protein. This new WPNI value (protein corrected) would be independent of powder protein content and hence be more indicative of the actual heat treatment it is intended to reflect.
\end{abstract}

whey protein nitrogen index / protein standardization / edible lactose powder / permeate powder / nonfat dry milk powder

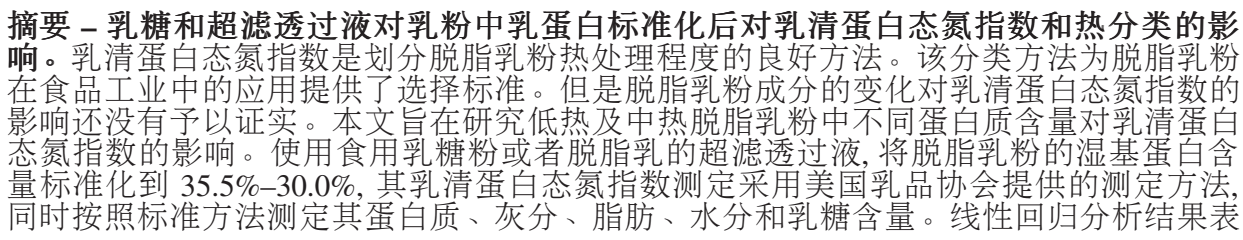

* Corresponding author (通讯作者): ptong@calpoly.edu 
明: 乳清蛋白态氮指数与低热及中热脱脂乳粉, (不同供应商提供) 的蛋白质含量均呈正相 关。例如: 低热脱脂乳粉 (B供应商) 在原始蛋白含量为 $34.3 \%$ (湿基)、可溶性乳清蛋白态 氮指数为 $6.38 \mathrm{mg}$ 时被认为是低热乳粉, 但是当用食用乳糖粉或者超滤透过液将湿基蛋白质 含量降低至 $31.89 \%$ 时, 则每克乳粉中可溶性乳清蛋白态氮的含量小于 $6.0 \mathrm{mg}$, 这样可能就被 归类为中热脱脂乳粉。这就表明使用乳糖或者超滤透过液进行脱脂乳的标准化可能改变其 乳清蛋白态氮指数, 并影响其热分类结果。因此, 并影响其热分类结果。因此, 建议采用每克 蛋白中可溶性乳清蛋白氮来改进乳清蛋白态氮指数的计算方法。该种方法中乳清蛋白态氮 指数 (蛋白质进行了校正) 与脱脂乳粉中的蛋白质含量无关, 因此更能反应出热处理的真实 的程度。

\section{乳清蛋白态氮指数 / 乳蛋白标准化 / 食用乳糖粉 / 超滤透过液 / 脱脂乳粉}

Résumé - Impact de la standardisation en protéines de poudre de lait avec du lactose ou du perméat sur l'indice d'azote des protéines solubles et sur sa classification thermique. L'indice d'azote des protéines solubles (WPNI) est une méthode bien connue pour classifier les poudres de lait écrémé selon leur traitement thermique. Cette classification procure un critère pour sélectionner ces poudres pour des applications alimentaires. Cependant, les effets de leurs variations de composition sur le WPNI n'est pas bien documenté. L'objectif de cette étude était de déterminer les effets de changements de teneur en protéines dans des poudres de lait écrémé «low heat » et «medium heat » sur leur WPNI. Des poudres alimentaires de lactose ou de perméat d'ultrafiltration de lait écrémé ont été utilisées pour standardiser à la baisse la poudre de lait écrémé à partir d'une teneur en protéines de 35,5-30 \% sur matière sèche. Le WPNI de ces poudres standardisées a été calculé selon la méthode de l'ADPI (American Dairy Products Institute). Les poudres ont également été analysées pour leur teneur en protéines, cendres, matière grasse, eau et lactose par les méthodes standards pour en connaître la composition. L'utilisation de la régression linéaire a permis de mettre en évidence que le WPNI est positivement associé à la teneur en protéines pour des poudres «low heat» et «medium heat» provenant de plusieurs fournisseurs. Par exemple, une poudre de lait écrémé « low heat» (fournisseur B) avec une teneur en protéines initiale de 34,3\% (sur matière sèche) et un WPNI de 6,38 mg d'azote soluble des protéines de lactosérum (classée comme poudre « low heat ») avait son WPNI réduit à moins de 6,0 mg d'azote soluble par gramme de poudre quand elle était standardisée à une teneur en protéines de moins de 31,89\% (sur matière sèche) avec de la poudre de lactose ou de perméat, ce qui pourrait la reclasser comme poudre «medium heat ». Nous pouvons conclure que la standardisation de la poudre de lait écrémé par du lactose ou du perméat change sa valeur de WPNI et peut avoir un effet sur sa classification. Nous proposons une approche modifiée pour calculer le WPNI basée sur l'azote soluble des protéines de lactosérum par gramme de protéines. Cette nouvelle valeur de WPNI (corrigée en protéines) serait indépendante de la teneur en protéines de la poudre et par conséquent indiquerait mieux le traitement thermique réel qu'il est censé traduire.

indice d'azote des protéines solubles / standardisation en protéines / poudre de lactose alimentaire / poudre de perméat / poudre de lait écrémé

\section{INTRODUCTION}

Prior to drying, skim milk or skim milk concentrates can be given an additional heat treatment to alter the functional properties such as solubility, water holding, emulsification, and viscosity of the resulting dried powder [16]. It has been shown that this heat treatment is related to the extent of whey protein denatured [9].
The above relationship was used to establish the widely practiced heat classification system based on the Whey Protein Nitrogen Index (WPNI) analytical method [1]. In this method, the turbidity of a sample is measured and then correlated to a standard curve to determine the soluble whey protein nitrogen content in $1 \mathrm{~g}$ sample of milk powder [12]. Nonfat dry milk (NFDM) powders that have a WPNI value greater than or equal to $6.0 \mathrm{mg}$ soluble 
whey protein nitrogen per g powder are defined as low heat, between 1.51-5.99 mg soluble whey protein nitrogen per g powder are defined as medium heat, and less than or equal to $1.51 \mathrm{mg}$ soluble whey protein nitrogen per $\mathrm{g}$ powder are defined as high heat [1].

The heat classification system for milk powders has been used commercially over the years to provide general guidelines for various food applications. However, the value of the WPNI method has not been without criticism. It has been reported that the soluble whey protein nitrogen level can be influenced by natural variation in the concentration of the proteins in the raw milk and thus, has limited value as an index of heating history $[5,10,14,15,19]$.

There is an interest in standardizing the protein content of milks destined for manufacture into skim milk powder (SMP) [11]. According to Codex Alimentarius 207 [2], the use of milk derived permeate or edible lactose can be used to standardize the protein content of milk powder or milk destined for manufacture into SMP to $34 \%$ protein on a solids-not-fat (SNF) basis. Recently, it has been reported that amendment to European Commission (EC) directive will allow for protein standardization of SMP with $34 \%$ content (SNF) in line with Codex Alimentarius [3]. For example, a SMP containing moisture content of $4 \%, 1.4 \%$ fat content and $32.6 \%$ protein (wet basis) translates into $34 \%$ protein content on a SNF basis. Fluid milk application studies on protein standardization of milk have focused to improve the yield for cheese making $[6,18]$, functional properties such as heat stability [17], and storage stability of UHT milk [7].

Despite the reported limitations of the WPNI method, it remains a tool widely utilized in commercial practice. In addition, expectations for consistent composition and functionality of all dairy ingredients drive interest in protein standardization. Further, little information is available to document the influence of protein standardization on heat classification of milk powders. Thus, the present study was conducted to determine the impact of downwards protein standardization of nonfat dry milk on its WPNI value and its subsequent heat classification.

\section{MATERIALS AND METHODS}

\subsection{Materials}

Commercial samples of low heat and medium heat NFDM were obtained from three different manufacturers: A (low heat); $\mathrm{B}$ (low heat); and $\mathrm{C}$ (medium heat).

\subsection{Sample preparation}

Commercial edible lactose powder (ELP) and commercial permeate powder (PP) from skim milk ultrafiltration were obtained and used for downwards protein standardization of low heat and medium heat skim milk powder. While standardization below $34 \%$ protein on a SNF basis is not allowed by Codex Alimentarius 207, we studied such values to better confirm the observed trends of the effects of protein standardization of SMP. Figure 1 shows protein standardization was achieved by dry blending of predetermined quantity of ELP or PP to low heat NFDM to achieve target protein content. Protein standardized samples are presented according to the level of protein and type of standardization, for example, NFDM powder standardized with ELP standardized to $34 \%$ protein content was named MPSELP34.

\subsection{Methods}

\subsubsection{Whey protein nitrogen index (WPNI)}

Samples of low heat, medium heat and standardized SMP were analyzed for 


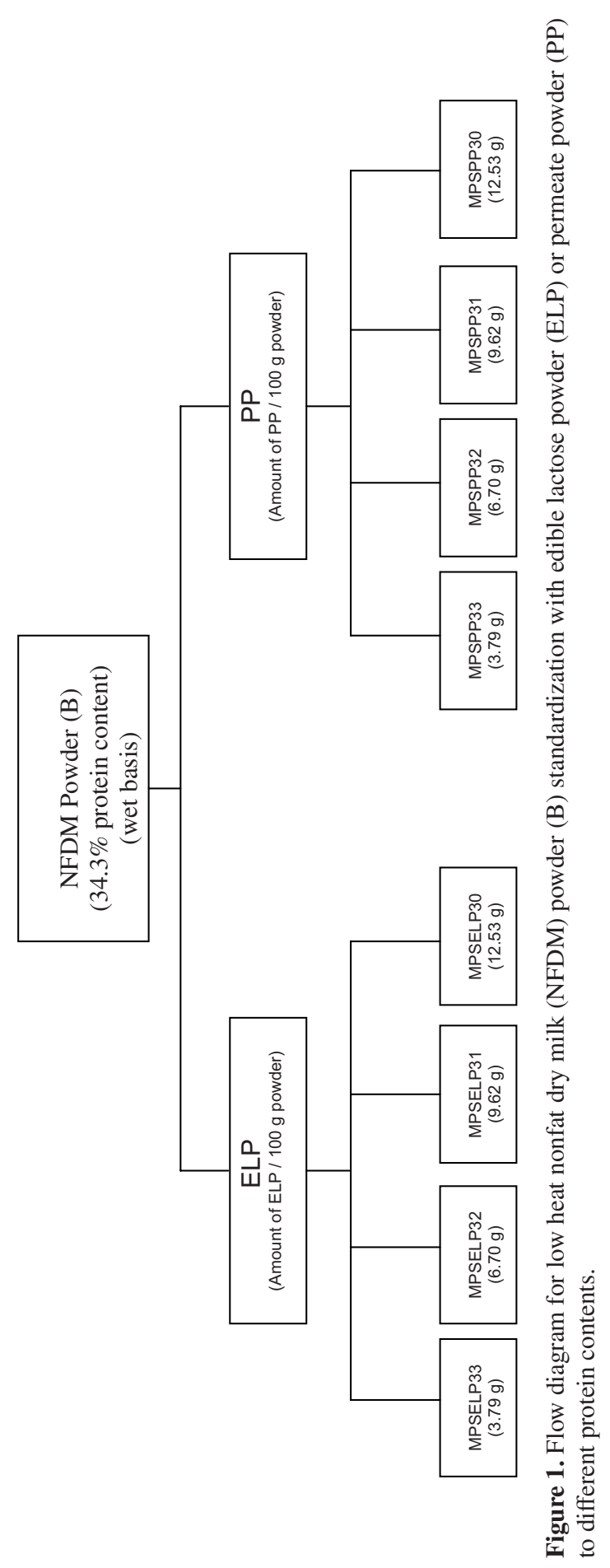


WPNI by American Dairy Products Institute (ADPI) method [1]. ADPI has adopted the most commonly used WPNI method, which was originally developed by Harland and Ashworth [8] and further modified by Kuramoto et al. [12] and Leighton [13]. This turbidimetric method is based on removal of casein and denatured whey protein (DWPN) from undenatured whey protein (UWPN) by precipitation with saturated $\mathrm{NaCl}$ solution. Then, 2 drops of $10 \% \mathrm{HCl}$ is added to a test tube containing $1 \mathrm{~mL}$ sample of filtrate and $10 \mathrm{~mL}$ of saturated $\mathrm{NaCl}$ solution. Then, the developed turbidity of the sample is measured at $420 \mathrm{~nm}$ and compared against a standard curve generated from analysis of "standard" milk powders of WPNI value obtained from ADPI low heat NFDM (WPNI of $7.32 \mathrm{mg} \mathrm{N} \cdot \mathrm{g}^{-1}$ ) and high heat NFDM (WPNI of $0.32 \mathrm{mg} \mathrm{N} \cdot \mathrm{g}^{-1}$ ) using the above method. It is assumed that developed turbidity corresponds to the amount of UWPN in the original milk powders. Hence, results are reported as mg soluble whey protein nitrogen per $g$ of powder.

\subsubsection{Composition analysis}

Samples of low heat and medium heat NFDM powder were analyzed for protein, ash, moisture, fat, and lactose content. Total nitrogen (TN) was determined in the low heat NFDM, medium heat NFDM, ELP, PP and standardized SMP samples by Kjeldahl method (AOAC, method number 991.20; 33.2.11) [4]. Ash was determined by ignition at $550{ }^{\circ} \mathrm{C}$ in an electric muffle furnace (AOAC, method number 945.46; 33.2.10) [4]. Fat content was determined by Mojonnier method (AOAC, method number 989.05; 33.2.26) [4]. Free moisture was determined by direct forced air oven drying method (AOAC, method number 990.20; 33.2.44) [4]. Lactose content was determined in low heat NFDM, medium heat NFDM, and standardized SMP by difference.

\subsubsection{Statistical analyses}

Results were evaluated using a multiple linear regression in both Minitab Version 14.2 (Minitab, Inc., State College, PA, USA) and Data Desk Version 6.1 (Data Description, Inc., Ithaca, NY, USA) software. Possible predictors of WPNI that were included in the model were powder supplier (A, B, C), powder type (low heat, medium heat), standardization method (ELP, PP), and protein level (35.5$30 \%)$.

\section{RESULTS AND DISCUSSION}

\subsection{Descriptive NFDM composition}

Crude protein analysis of three commercial NFDM low heat (A), low heat (B), and medium heat $(\mathrm{C})$ along with ELP and PP are presented in Table I. The average crude protein content observed for low heat NFDM (A), low heat NFDM (B) and medium heat NFDM (C) was $35.1 \%$, $34.3 \%$, and $35.5 \%$ respectively, $0 \%$ for ELP and $2.40 \%$ for the PP. PP does not have true protein and hence, the $2.4 \%$ of crude protein value really reflects nonprotein nitrogen content of permeate. A detailed analysis of the three samples is discussed below.

\subsubsection{Low heat NFDM (A)}

Effect of protein standardization on composition of low heat NFDM (A) is summarized in Table II. Low heat NFDM (A) with $35.1 \%$ protein content on wet basis $(36.3 \%$ on dry basis; $36.9 \%$ on SNF basis) was downward standardized to $34 \%, 33 \%, 32 \%, 31 \%$ and $30 \%$ protein 
Table I. Crude protein analysis (wet, dry, SNF basis) of the three commercial milk powders (nonstandardized), edible lactose powder and milk permeate powder.

\begin{tabular}{lccc}
\hline Ingredient & \multicolumn{3}{c}{ Crude protein* $^{*}$} \\
\cline { 2 - 4 } & Wet basis $^{1}$ & Dry basis $^{2}$ & SNF basis $^{3}$ \\
\hline Low heat SMP (A) & $35.1 \pm 0.0$ & $36.32 \pm 0.0$ & $36.9 \pm 0.0$ \\
Low heat SMP (B) & $34.3 \pm 0.2$ & $35.66 \pm 0.3$ & $35.97 \pm 0.3$ \\
Medium heat SMP (C) & $35.5 \pm 0.1$ & $36.71 \pm 0.0$ & $37.05 \pm 0.1$ \\
Edible lactose powder & $0.00 \pm 0.0$ & $0.00 \pm 0.0$ & $0.00 \pm 0.0$ \\
Milk permeate powder & $2.40 \pm 0.1$ & $2.50 \pm 0.1$ & $2.50 \pm 0.1$ \\
\hline
\end{tabular}

$\mathrm{n}=2$.

${ }^{*}$ Crude protein $=$ Total nitrogen $* 6.38$.

1 Wet basis $=$ As is.

2 Dry basis $=100-\%$ free moisture content.

${ }^{3}$ SNF basis $=100-\%$ free moisture content $-\%$ fat content.

with ELP. The corresponding protein content on dry basis and SNF basis for low heat NFDM (A) is listed in Table II. WPNI values for the standardized samples were observed to decrease up to $15 \%$ with decrease in protein content from $35.1-30 \%$ protein. A decrease in WPNI values of ELP standardized samples indicates that ELP does contribute towards WPNI. Similarly, ash values for the standardized samples were observed to decrease up to $15 \%$ with decrease in protein content from $35.1-30 \%$ protein. The decrease of ash values is attributed to the observed low mineral content of the ELP. Moisture content for the ELP standardized samples was observed to decrease up to $17 \%$, with decrease in protein and hence, results in decrease of protein to lactose ratio. Fat content for the ELP standardized samples were observed to decrease up to $37 \%$ because ELP has negligible fat contribution.

\subsubsection{Low heat NFDM (B)}

Effect of protein standardization on the composition of low heat NFDM (B) is summarized in Table III. Low heat NFDM (B) with $34.3 \%$ protein content on wet basis $(35.7 \%$ on dry basis; $36 \%$ on
SNF basis) was downward standardized to $33 \%, 32 \%, 31 \%$ and $30 \%$ protein with ELP or PP. The corresponding protein content on dry basis and SNF basis for downward standardized low heat NFDM (B) is listed in Table III.

WPNI values for the ELP standardized samples were observed to decrease up to $11 \%$ as protein was standardized downwards from $35.3-30 \%$. A decrease in WPNI values of ELP standardized samples indicates that ELP does contribute towards WPNI. Similarly, ash values for the ELP standardized samples were observed to decrease up to $13 \%$, with a decrease in protein content of the SMP. The decrease of ash values is attributed to the low mineral content of the ELP. Moisture content for the ELP standardized samples were observed to decrease up to $8 \%$, with decrease in protein and hence, results in decrease of protein to lactose ratio. Fat content for the ELP standardized samples were observed to decrease up to $35 \%$ with decrease in protein content from $34.3-30 \%$ protein because ELP has negligible fat contribution.

WPNI values for the PP standardized samples were observed to decrease up to $12 \%$ as protein was standardized downwards from $34.3-30 \%$. A decrease in WPNI values of PP standardized samples 
Table II. Composition analysis (mean \pm SD) of low heat NFDM powder (A) standardized with edible lactose powder.

\begin{tabular}{|c|c|c|c|c|c|c|c|c|c|}
\hline $\begin{array}{l}\text { Sample } \\
\text { type }\end{array}$ & $\begin{array}{c}\text { Target } \\
\text { protein }\end{array}$ & 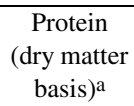 & $\begin{array}{c}\text { Protein } \\
\text { SNF } \\
\text { basis }\end{array}$ & b WPNI & b Ash & ${ }^{b}$ Moisture & b Fat & b Lactose* & $\begin{array}{l}\text { Protein/ } \\
\text { Lactose }\end{array}$ \\
\hline Control & 35.1 & 36.3 & 36.9 & $6.36 \pm 0.4$ & $7.66 \pm 0.0$ & $3.36 \pm 0.1$ & $1.5 \pm 0.0$ & 52.4 & 0.67 \\
\hline MPSELP34 & 34.0 & 35.1 & 35.6 & $6.04 \pm 0.9$ & $7.52 \pm 0.1$ & $3.04 \pm 0.1$ & $1.45 \pm 0.0$ & 54.0 & 0.63 \\
\hline MPSELP33 & 33.0 & 34.0 & 34.5 & $5.84 \pm 0.2$ & $7.27 \pm 0.0$ & $2.93 \pm 0.0$ & $1.37 \pm 0.1$ & 55.4 & 0.60 \\
\hline MPSELP32 & 32.0 & 33.0 & 33.4 & $5.79 \pm 2.0$ & $7.00 \pm 0.1$ & $2.89 \pm 0.1$ & $1.25 \pm 0.1$ & 56.9 & 0.56 \\
\hline MPSELP31 & 31.0 & 31.9 & 32.3 & $5.54 \pm 0.2$ & $6.82 \pm 0.0$ & $2.88 \pm 0.1$ & $1.11 \pm 0.0$ & 58.2 & 0.53 \\
\hline MPSELP30 & 30.0 & 30.9 & 31.2 & $5.41 \pm 0.2$ & $6.49 \pm 0.0$ & $2.79 \pm 0.1$ & $0.95 \pm 0.1$ & 59.8 & 0.50 \\
\hline
\end{tabular}

$\mathrm{n}=2$.

Results expressed in $\mathrm{g} / 100 \mathrm{~g}$ of milk powder.

a Dry matter basis $=100-\%$ free moisture.

b Results based on wet basis.

* Calculated value (by difference).

MPSELP = Milk powder standardized with edible lactose powder.

Table III. Composition analysis (mean \pm SD) of low heat NFDM powder (B) standardized with edible lactose powder or permeate powder.

\begin{tabular}{lccccccccc}
\hline $\begin{array}{l}\text { Sample } \\
\text { type }\end{array}$ & $\begin{array}{c}\text { Target } \\
\text { protein } \\
\left(\begin{array}{c}\text { (dry matter } \\
\text { basis) }\end{array}\right.\end{array}$ & $\begin{array}{c}\text { Protein } \\
\text { (SNF } \\
\text { basis) }\end{array}$ & b WPNI & b Ash & b Moisture & b Fat & $\begin{array}{c}\text { b Lactose* Protein/ } \\
\text { Lactose }\end{array}$ \\
\hline Control & 34.3 & 35.7 & 36.0 & $6.38 \pm 0.1$ & $7.74 \pm 0.0$ & $3.81 \pm 0.3$ & $0.83 \pm 0.0$ & 53.4 & 0.64 \\
MPSELP33 & 33.0 & 34.1 & 34.3 & $6.18 \pm 0.0$ & $7.45 \pm 0.0$ & $3.18 \pm 0.1$ & $0.68 \pm 0.0$ & 55.7 & 0.59 \\
MPSELP32 & 32.0 & 33.1 & 33.3 & $6.03 \pm 0.0$ & $7.23 \pm 0.0$ & $3.38 \pm 0.1$ & $0.63 \pm 0.1$ & 56.8 & 0.56 \\
MPSELP31 & 31.0 & 32.2 & 32.3 & $5.89 \pm 0.1$ & $7.10 \pm 0.1$ & $3.61 \pm 0.4$ & $0.57 \pm 0.0$ & 57.7 & 0.54 \\
MPSELP30 & 30.0 & 31.1 & 31.3 & $5.68 \pm 0.1$ & $6.74 \pm 0.0$ & $3.50 \pm 0.0$ & $0.54 \pm 0.0$ & 59.2 & 0.51 \\
& & & & & & & & & \\
MPSPP33 & 33.0 & 34.3 & 34.5 & $6.23 \pm 0.1$ & $7.73 \pm 0.1$ & $3.66 \pm 0.3$ & $0.83 \pm 0.1$ & 54.8 & 0.60 \\
MPSPP32 & 32.0 & 33.2 & 33.5 & $5.98 \pm 0.0$ & $7.72 \pm 0.1$ & $3.70 \pm 0.2$ & $0.72 \pm 0.0$ & 55.9 & 0.57 \\
MPSPP31 & 31.0 & 32.2 & 32.4 & $5.86 \pm 0.0$ & $7.70 \pm 0.1$ & $3.68 \pm 0.1$ & $0.67 \pm 0.1$ & 57.0 & 0.54 \\
MPSPP30 & 30.0 & 31.3 & 31.5 & $5.60 \pm 0.1$ & $7.70 \pm 0.1$ & $4.13 \pm 0.1$ & $0.60 \pm 0.1$ & 57.6 & 0.52 \\
\hline
\end{tabular}

$\mathrm{n}=2$.

Results expressed in $\mathrm{g} / 100 \mathrm{~g}$ of milk powder.

a Dry matter basis $=100-\%$ free moisture.

$\mathrm{b}$ Results based on wet basis.

* Calculated value (by difference).

MPSELP $=$ Milk powder standardized with edible lactose powder.

MPSPP $=$ Milk powder standardized with permeate powder. 
indicates that PP does contribute towards WPNI. Similarly, mean values of ash for PP standardized NFDM decreased up to $0.3 \%$. The very small changes in ash value are attributed to high mineral content of PP. Fat content for the PP standardized samples were observed to decrease up to $28 \%$ with decrease in protein content from $34.3-30 \%$ protein, as milk powder replaced with PP has fat content less than $0.1 \%$. Moisture content for the PP standardized samples were observed to increase up to $8 \%$, with decrease in protein and hence, results in a decrease of protein to lactose ratio.

\subsubsection{Medium heat NFDM (C)}

Effect of protein standardization on the composition of medium heat NFDM (C) is summarized in Table IV. Medium heat NFDM (C) with $35.5 \%$ protein content on wet basis $(36.7 \%$ on dry basis; $37.0 \%$ on SNF basis) was downward standardized to $34 \%, 32 \%$ and $30 \%$ protein with ELP or PP. WPNI values for ELP standardized samples were observed to decrease up to $18 \%$ as protein was standardized downwards from $35.5-30 \%$. A decrease in WPNI values of ELP standardized samples indicates that ELP does contribute towards WPNI. Similarly, ash values for the ELP standardized samples were observed to decrease up to $15 \%$, with a decrease in protein content of the SMP. The decrease of ash values is attributed to the low mineral content of the ELP. Moisture content for the ELP standardized samples was observed to decrease up to $9 \%$, with decrease in protein and hence, results in decrease of protein to lactose ratio. Fat content for the ELP standardized samples was observed to decrease up to $56 \%$ with decrease in protein content from $35.5-30 \%$ because ELP has negligible fat contribution.

WPNI values for PP standardized samples were observed to decrease up to $15 \%$ as protein was standardized downwards from $35.5-30 \%$. A decrease in WPNI values of PP standardized samples indicates that PP does contribute towards WPNI. Similarly, mean values of ash for PP standardized NFDM decreased up to $0.3 \%$. The very small changes in ash value are attributed to high mineral content of PP. Fat content for the PP standardized samples was observed to decrease up to $25 \%$ with a decrease in the protein content from $35.5-30 \%$ protein as milk powder replaced with PP has fat content less than $0.1 \%$. Moisture content for the PP standardized samples were observed to increase up to $11 \%$, with decrease in protein and hence, results in decrease of protein to lactose ratio.

\subsection{Linear regression analysis}

Based on the results obtained from Tables II-IV, the relationship between protein level and WPNI was analyzed using two multiple linear regression models. Two models are necessary because low and medium heat samples were not available from all three suppliers. Each model was tested for different effects within the experiment. Model 1 tests for differences between low and medium heat powders from supplier C only. Model 2 uses all three suppliers for only low heat powder.

\subsubsection{Model 1}

Model 1 compares WPNI and protein level for both medium and low heat NFDM powders. Only samples from Supplier C were used because only Supplier C had both low heat and medium heat NFDM. The powders were standardized with either ELP or PP to adjust each sample to a specified target protein level between $30 \%$ and $34 \%$. WPNI values for ELP standardized low heat milk powder were found to be 
Table IV. Composition analysis (mean \pm SD) of medium heat NFDM (C) standardized with edible lactose powder or permeate powder.

\begin{tabular}{|c|c|c|c|c|c|c|c|c|c|}
\hline $\begin{array}{l}\text { Sample } \\
\text { type }\end{array}$ & $\begin{array}{l}{ }^{\text {a }} \text { Ta rget } \\
\text { protein }\end{array}$ & $\begin{array}{c}\text { Protein } \\
\text { (dry matter } \\
{\text { basis })^{\mathrm{a}}}^{\text {a }}\end{array}$ & $\begin{array}{c}\text { Protein } \\
\text { (SNF } \\
\text { basis) }\end{array}$ & b WPNI & b Ash & $\mathrm{b}$ Moisture & b Fat & b Lactose* & $\begin{array}{l}\text { Protein } \\
\text { Lactose }\end{array}$ \\
\hline Control & 35.5 & 36.7 & 37.0 & $3.43 \pm 0.0$ & $7.75 \pm 0.0$ & $3.30 \pm 0.3$ & $0.88 \pm 0.1$ & 52.6 & 0.68 \\
\hline MPSELP34 & 34.0 & 35.1 & 35.4 & $3.11 \pm 0.1$ & $7.47 \pm 0.0$ & $3.25 \pm 0.3$ & $0.67 \pm 0.1$ & 54.6 & 0.62 \\
\hline MPSELP32 & 32.0 & 33.0 & 33.2 & $3.00 \pm 0.1$ & $7.05 \pm 0.0$ & $3.09 \pm 0.2$ & $0.44 \pm 0.1$ & 57.4 & 0.56 \\
\hline MPSELP30 & 30.0 & 30.9 & 31.0 & $2.80 \pm 0.2$ & $6.61 \pm 0.0$ & $2.99 \pm 0.3$ & $0.39 \pm 0.0$ & 60.0 & 0.50 \\
\hline MPSPP34 & 34.0 & 35.2 & 35.5 & $3.32 \pm 0.1$ & $7.80 \pm 0.0$ & $3.40 \pm 0.1$ & $0.84 \pm 0.1$ & 53.9 & 0.63 \\
\hline MPSPP32 & 32.0 & 33.2 & 33.4 & $3.16 \pm 0.3$ & $7.76 \pm 0.0$ & $3.57 \pm 0.1$ & $0.74 \pm 0.1$ & 55.9 & 0.57 \\
\hline MPSPP30 & 30.0 & 31.1 & 31.4 & $2.92 \pm 0.0$ & $7.78 \pm 0.0$ & $3.65 \pm 0.2$ & $0.66 \pm 0.1$ & 57.9 & 0.52 \\
\hline
\end{tabular}

$\mathrm{n}=2$.

Results expressed in $\mathrm{g} / 100 \mathrm{~g}$ of milk powder.

${ }^{\mathrm{a}}$ Dry matter basis $=100-\%$ free moisture.

$\mathrm{b}$ Results based on wet basis.

* Calculated value (by difference).

MPSELP = Milk powder standardized with edible lactose powder.

MPSPP $=$ Milk powder standardized with permeate powder.

$6.38 \pm 0.2,5.96 \pm 0.0,5.61 \pm 0.1 \mathrm{mg}$ nitrogen per g powder for $34 \%, 32 \%$ and $30 \%$ protein respectively. WPNI values for PP standardized low heat milk powder were found to be $6.39 \pm 0.2,6.09 \pm 0.1$, and $5.74 \pm 0.1 \mathrm{mg}$ nitrogen per g powder for $34 \%, 32 \%$ and $30 \%$ protein respectively. WPNI value for control (unadjusted) low heat milk powder sample was found to be $6.90 \pm 0.1 \mathrm{mg}$ nitrogen per $\mathrm{g}$ powder for $35.5 \%$ protein. Initially, the control samples were omitted from the analysis so that the interaction of standardization and protein level could be tested. Because the control samples did not share any target protein levels with the ELP and PP samples, this interaction cannot be tested with control samples in the data. After omitting the control samples, data from 24 standardized powder samples were analyzed in Model 1A. The purpose of this model was to estimate whether the different standardizations and powder types have differing relationships between protein level and
WPNI. The equation for Model 1A is

$$
\begin{aligned}
& E(W P N I)=\beta_{0}+\beta_{\text {Pro }}\left(x_{\text {Pro }}-32\right) \\
& +\beta_{\text {Med }} x_{\text {Med }}+\beta_{\text {PP }} x_{\text {PP }}+\beta_{\text {Pro } * \text { Med }}\left(x_{\text {Pro }}-32\right) \\
& \times x_{\text {Med }}+\beta_{\text {Pro } * \mathrm{PP}} \times\left(x_{\text {Pro }}-32\right) x_{\text {PP }} \\
& +\beta_{\text {Med } * \mathrm{PP}} x_{\text {Med }} x_{\mathrm{PP}}+\beta_{\text {Pro } * \text { Med } * P P}\left(x_{\text {Pro }}-32\right) \\
& \times x_{\text {Med }} x_{\mathrm{PP}}
\end{aligned}
$$

where $E(W P N I)$ is mean WPNI, ( $x_{\text {Pro }}-$ $32)$ is the target protein level centered to a value of $32 \%$, and $x_{\mathrm{Med}}$ and $x_{\mathrm{PP}}$ are indicator variables representing medium heat NFDM and standardization with permeate. The $\beta$ terms represent the effects of these variables and their interactions on the WPNI level.

Model 1A explains $99.6 \%$ of the variation in the WPNI values of the samples. Initial tests showed no significant difference in mean WPNI between the lactose and permeate samples $(p=0.38)$, so all terms involving standardization effects were removed to simplify the model, and the control samples were restored. We refer to this model as Model 1B, which has 


\section{Scatterplot of WPNI vs target protein}

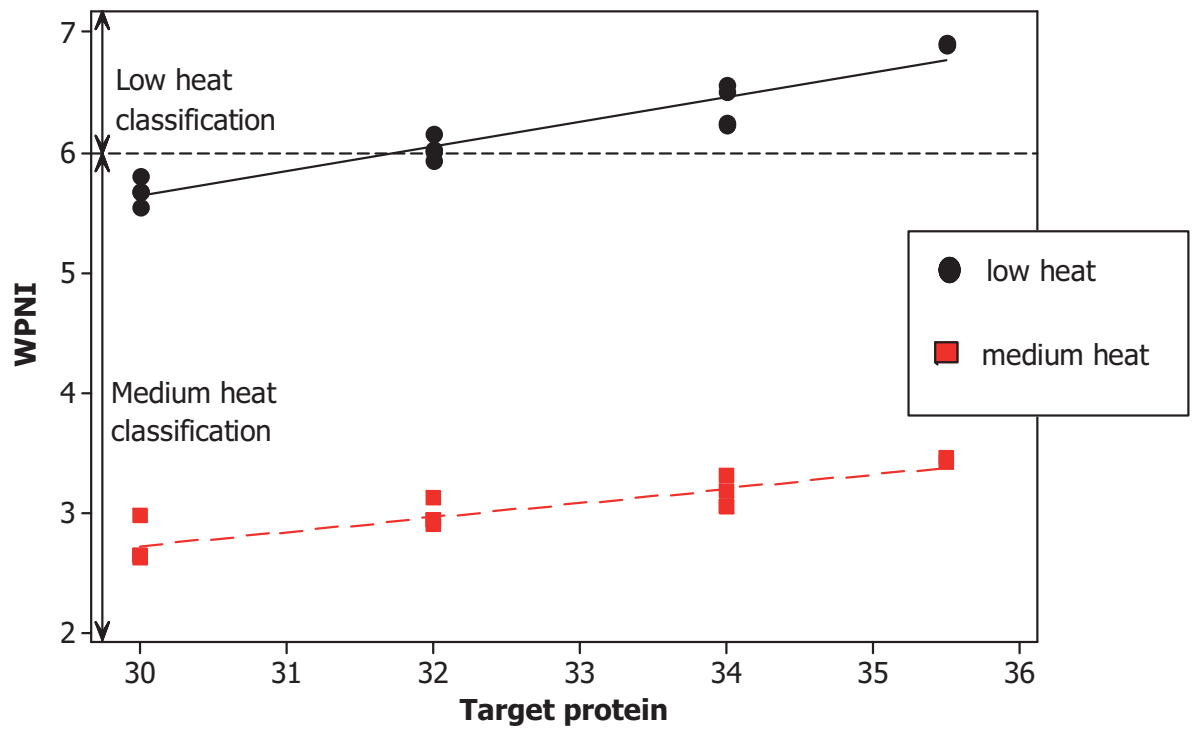

Figure 2. Effect of protein standardization on WPNI (mg of WPN. $\mathrm{g}^{-1}$ of powder) of low heat or medium heat SMP.

equation

$$
\begin{aligned}
& E(W P N I)=\beta_{0}+\beta_{\text {Pro }}\left(x_{\text {Pro }}-32\right) \\
& +\beta_{\text {Med }} x_{\text {Med }}+\beta_{\text {Pro } * \text { Med }}\left(x_{\text {Pro }}-32\right) x_{\text {Med }}
\end{aligned}
$$

This model explains $99.5 \%$ of the variation in WPNI. After adjusting for protein level, mean WPNI of medium heat powder was significantly lower than that of low heat powder $(p<0.001)$. At the median protein level of $32 \%$, medium heat powder had an average WPNI that was $3.10 \mathrm{mg}$ nitrogen per $\mathrm{g}$ of powder, lower than low heat powder. After adjusting for NFDM powder type, protein level was positively associated with WPNI $(p<0.001)$. In addition, protein level had a greater effect on WPNI in low heat powder than in medium heat powder $(p=0.002)$. These effects are described in greater detail below.

Model 1B produced two equations to describe the relationship between protein and WPNI. These equations are displayed along with the data in Figure 2. For low heat powder,

$$
E(W P N I)=6.053+0.206\left(x_{\text {Pro }}-32\right)
$$

where $\left(x_{\text {Pro }}-32\right)$ is the deviation in percentage points from $32 \%$ protein. Therefore, at $32 \%$ protein, the low heat powder is estimated to have a mean WPNI of $6.053 \mathrm{mg}$ nitrogen per g powder. Each increase of one percentage point in protein is associated with an increase of $0.206 \mathrm{mg}$ nitrogen per $g$ powder in mean WPNI for low heat powder. With $95 \%$ confidence the change in WPNI per percent of protein is between 0.170 and $0.242 \mathrm{mg}$ nitrogen per $\mathrm{g}$ powder.

For medium heat powder,

$$
E(W P N I)=2.952+0.119\left(x_{\text {Pro }}-32\right) .
$$

Therefore, at $32 \%$ protein, medium heat powder is estimated to have a mean WPNI of $2.952 \mathrm{mg}$ nitrogen per g powder. Each increase of 1 percentage point in protein is associated with an increase of $0.119 \mathrm{mg}$ 
nitrogen per $\mathrm{g}$ powder in mean WPNI for medium heat powder. With $95 \%$ confidence the change in WPNI per percent of protein is between 0.083 and $0.156 \mathrm{mg}$ nitrogen per g powder, which is substantially lower than the effect of changing protein on low heat powders.

\subsubsection{Model 2}

Model 2 compares WPNI and protein for the low heat powders from suppliers A, $\mathrm{B}$, and C. The purpose of Model 2 was to determine if the effect of protein on WPNI differed based on standardization or supplier. As in the earlier model, samples were standardized with either ELP or PP to target protein levels between $30 \%$ and $34 \%$. As before, the control samples were initially omitted from the analysis to test for interaction effects. Data from 41 samples were used in this analysis, Model 2A, which has equation

$E(W P N I)=\beta_{0}+\beta_{\text {Pro }}\left(x_{\text {Pro }}-32\right)$

$+\beta_{\mathrm{A}} x_{\mathrm{A}}+\beta_{\mathrm{B}} x_{\mathrm{B}}+\beta_{\text {Per }} x_{\mathrm{PP}}+\beta_{\text {Pro } * \mathrm{~A}}\left(x_{\text {Pro }}-32\right)$

$\times x_{\mathrm{A}}+\beta_{\text {Pro*B }}\left(x_{\text {Pro }}-32\right) x_{\mathrm{B}}+\beta_{\text {Pro } * \mathrm{PP}}$

$\times\left(x_{\mathrm{Pro}}-32\right) x_{\mathrm{PP}}+\beta_{\mathrm{B} * \mathrm{PP}} x_{\mathrm{B}} x_{\mathrm{PP}}+\beta_{\mathrm{Pro} * \mathrm{~B} * \mathrm{PP}}$ $\times\left(x_{\text {Prot }}-32\right) x_{\mathrm{B}} x_{\mathrm{PP}}$

where $E(W P N I),\left(x_{\text {Pro }}-32\right)$, and $x_{\mathrm{PP}}$ are defined as before while $x_{\mathrm{A}}$ and $x_{\mathrm{B}}$ are indicator variables for suppliers A and B.

Model 2A explains $89.4 \%$ of the variation in the WPNI values of the samples. The poorer fit is due to larger variation in the WPNI values from supplier A. Initial tests again showed no significant difference in mean WPNI between the lactose and permeate samples $(p=0.38)$, so all terms involving standardization effects were removed from the model, and the control samples were restored. We refer to this model as Model 2B with equation

$E(W P N I)=\beta_{0}+\beta_{\text {Pro }}\left(x_{\text {Pro }}-32\right)+\beta_{\mathrm{A}} x_{\mathrm{A}}$ $+\beta_{\mathrm{B}} x_{\mathrm{B}}+\beta_{\text {Pro*A }}\left(x_{\text {Prot }}-32\right) x_{\mathrm{B}}+\beta_{\text {Pro* }}$ $\times\left(x_{\text {Prot }}-32\right) x_{\mathrm{C}}$.
Model 2B explains $87.9 \%$ of the variation in WPNI values. After adjusting for supplier, protein level was positively associated with WPNI $(p<0.001)$. The effect of protein on WPNI did not differ significantly from one supplier to another ( $p=0.24)$. After adjusting for protein level, powder from supplier A had a mean WPNI significantly lower than either supplier B or C $(p<0.001)$. This difference is not surprising given that each suppliers' thermal processing of milk evaporation, spray drying conditions (all of which can effect WPNI) are likely different. No significant difference was detected in the mean WPNI of powder from suppliers B and $\mathrm{C}(p=0.26)$.

After simplifying the model by dropping insignificant terms, the equations describing the relationship between protein and WPNI in low heat powders from our three suppliers are

$$
\begin{aligned}
\text { Supplier A: } & E(W P N I)=5.741+0.187 \\
\times & \left(x_{\text {Pro }}-32\right) \\
\text { Supplier B: } & E(W P N I)=6.021+0.187 \\
\times & \left(x_{\text {Pro }}-32\right) \\
\text { Supplier C: } & E(W P N I)=6.063+0.187 \\
\times & \left(x_{\text {Pro }}-32\right) .
\end{aligned}
$$

Regardless of supplier, each increase of one percentage point in protein is associated with an increase of $0.187 \mathrm{mg}$ nitrogen per $g$ powder in the mean WPNI. With $95 \%$ confidence the true change in WPNI per percent of protein is between 0.168 and $0.207 \mathrm{mg}$ nitrogen per $\mathrm{g}$ of powder.

Figure 3 shows that some low heat powder samples had WPNI of less than $6.0 \mathrm{mg}$ nitrogen per $\mathrm{g}$ powder, which would change the heat classification of the powder from low to medium heat. For supplier A, the change from low heat to medium heat classification is estimated to occur when protein is $33.39 \%$ on wet basis (34.6 on dry basis; 35.1 on SNF basis). These changes in classification are significant because they occur at protein values before the legal minimum of $34 \%$ protein 
on SNF basis. For suppliers B and C, the change from low heat to medium heat classification is estimated to occur when protein is $31.89 \%$ and $31.66 \%$ on wet basis (33.1 on dry basis, 33.3 on SNF basis and 32.7 on dry basis, 33 on SNF basis) respectively.

The results of the present study indicate that WPNI value of SMP is influenced by the protein level; however, protein has a larger effect on WPNI for low heat powders compared to medium heat powders. In some cases, this change in WPNI changes the actual heat classification (Fig. 2), suggesting that selection of milk powder based on traditional WPNI value (standard uncorrected) could be misleading under some situations of protein standardization.

\subsection{Proposed modification of heat classification measure}

The turbidimetric method is the standard method for heat classification of milk powder. Since there is natural variation in the protein concentration of raw milk, any indicator of functionality of SMP turbidity should correct for the protein level. Further, in light of allowable downwards protein standardization and its effects reported here on traditional WPNI value, use of uncorrected WPNI may not be desirable. We propose a modified classification measure using $\mathrm{mg}$ of whey protein nitrogen per $\mathrm{g}$ of protein $\left(\mathrm{WPNI}_{\text {pcorr }}\right)$.

Low heat NFDM is defined as having a WPNI of $6.0 \mathrm{mg}$ soluble nitrogen per $\mathrm{g}$ powder or more. Dividing this value by a percent target protein level of 35.5 yields a $\mathrm{WPNI}_{\text {pcorr }}$ of $16.9 \mathrm{mg}$ soluble nitrogen per $g$ protein. Medium heat NFDM is defined as having a WPNI between 1.5 and $6.0 \mathrm{mg}$ soluble nitrogen per $\mathrm{g}$ powder. Dividing these values by the target protein percentage of 35.5 yields a $\mathrm{WPNI}_{\text {pcorr }}$ between 4.2 and $16.9 \mathrm{mg}$ soluble nitrogen per $g$ protein. Therefore for a percent protein content of 35.5, we define low heat NFDM as having a $\mathrm{WPNI}_{\text {pcorr }}$ value greater than or equal to $16.9 \mathrm{mg}$ nitrogen per $\mathrm{g}$ protein, and we define medium heat NFDM as having a $\mathrm{WPNI}_{\text {pcorr }}$ value between 4.22 and $16.9 \mathrm{mg}$ nitrogen per g protein. These cutoff values and additional values for other protein levels are shown in Tables V-VII.

To validate these proposed $\mathrm{WPNI}_{\text {pcorr }}$ levels for low and medium heat NFDM, a linear regression model was fit to the $\mathrm{WPNI}_{\text {pcorr }}$ data for supplier $\mathrm{C}$ using the powder type, standardization, target percent protein level, and their interactions as predictors. As before the model (Model 3A) was initially fit without using the control samples in order to test the effect of standardization type and its interactions. Model 3A has the same equation as Model $1 \mathrm{~A}$, but with $\mathrm{WPNI}_{\text {pcorr }}$ as the response variable. This model explains $99.6 \%$ of the variation in $\mathrm{WPNI}_{\text {pcorr }}$. The analysis shows no significant effect of standardization on $\mathrm{WPNI}_{\text {pcorr }}(p=0.33)$.

Removing all terms containing standardization type and restoring the control samples, we create Model 3B (Fig. 4). This model explains $99.5 \%$ of the variation in $\mathrm{WPNI}_{\text {pcorr }}$. This analysis shows that medium heat NFDM powder has a lower mean $\mathrm{WPNI}_{\text {pcorr }}$ than low heat NFDM powder $(p<0.01)$. However, there is no significant difference in mean $\mathrm{WPNI}_{\text {pcorr }}$ for different protein levels $(p=0.15)$, and the effect of protein on $\mathrm{WPNI}_{\text {pcorr }}$ does not differ significantly between low and medium heat powders $(p=0.66)$.

After removing the insignificant terms containing protein level, Model 3C was used to estimate the $\mathrm{WPNI}_{\text {pcorr }}$ for both types of NFDM with $35.5 \%$ (supplier C) protein content. Mean WPNI pcorr of all low heat powder from supplier $\mathrm{C}$ is between 18.72 and $19.16 \mathrm{mg}$ soluble nitrogen per $\mathrm{g}$ protein. Mean $\mathrm{WPNI}_{\text {pcorr }}$ for all medium heat powder from supplier $\mathrm{C}$ is between 9.04 and $9.48 \mathrm{mg}$ soluble nitrogen per $\mathrm{g}$ protein. Individual samples of low heat 


\section{Scatterplot of WPNI vs target protein}

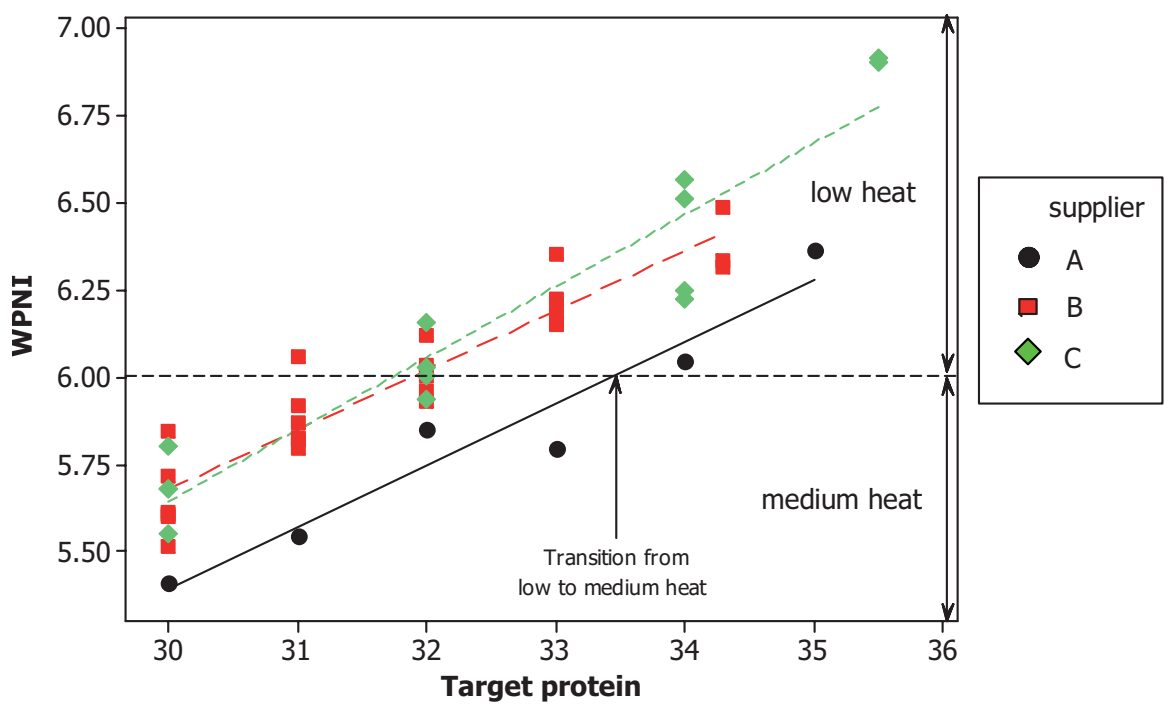

Figure 3. Effect of protein standardization on WPNI (mg of WPN. $\mathrm{g}^{-1}$ of powder) of low heat SMP.

Table V. Effect of absolute protein content on heat classification of milk powder based on soluble whey protein nitrogen $\cdot \mathrm{g}^{-1}$ of protein.

\begin{tabular}{|c|c|c|c|c|}
\hline & $\begin{array}{l}\text { Traditional } \\
\text { WPNI }\end{array}$ & & Modified $\mathrm{WPNI}_{\mathrm{pcorr}}$ & \\
\hline $\begin{array}{l}\text { Heat } \\
\text { classification }\end{array}$ & $\begin{array}{c}\text { NFDM } \\
\text { mg of soluble } \\
\text { WPN } \cdot \mathrm{g}^{-1} \text { powder }\end{array}$ & $\begin{array}{c}\text { NFDM }(\mathrm{A}) \\
\mathrm{mg} \text { of soluble } \\
\mathrm{WPN} \cdot \mathrm{g}^{-1} \text { protein } \\
\left(\text { Protein }=34.3 \mathrm{~g} \cdot 100 \mathrm{~g}^{-1}\right)\end{array}$ & $\begin{array}{c}\text { NFDM }(\mathrm{B}) \\
\mathrm{mg} \text { of soluble } \\
\text { WPN } \cdot \mathrm{g}^{-1} \text { protein } \\
\left(\text { Protein }=35.1 \mathrm{~g} \cdot 100 \mathrm{~g}^{-1}\right)\end{array}$ & $\begin{array}{c}\text { NFDM }(\mathrm{C}) \\
\text { mg of soluble } \\
\text { WPN.g } \mathrm{g}^{-1} \text { protein } \\
\left(\text { Protein }=35.5 \mathrm{~g} \cdot 100 \mathrm{~g}^{-1}\right)\end{array}$ \\
\hline Low heat & $\geqslant 6.0$ & $\geqslant 17.49$ & $\geqslant 17.09$ & $\geqslant 16.90$ \\
\hline Medium heat & $1.5-6.0$ & $4.37-17.49$ & $4.27-17.09$ & $4.22-16.90$ \\
\hline High heat & $\leqslant 1.5$ & $\leqslant 4.37$ & $\leqslant 4.27$ & $\leqslant 4.22$ \\
\hline
\end{tabular}

Protein is expressed g. $100 \mathrm{~g}^{-1}$ of powder as 34.3 or $0.343 ; 35.1$ or 0.351 ; and 35.5 or 0.355 .

powder may vary from 18.08 to $19.79 \mathrm{mg}$ soluble nitrogen per $\mathrm{g}$ protein, while individual samples of medium heat powder may vary from 8.40 to $10.11 \mathrm{mg}$ soluble nitrogen per $g$ protein. All estimates are made with $95 \%$ confidence. The model estimates of $\mathrm{WPNI}_{\text {pcorr }}$ for individual samples of low and medium heat powders fit comfortably within the ranges proposed for $35.5 \%$ protein in Table $\mathrm{V}$.
Any indicator of functionality of SMP needs to account for the protein level. For example, PP standardized low heat (B) SMP sample with a target of $32.0 \%$ protein content and a WPNI value of $5.98 \mathrm{mg}$ soluble nitrogen per $\mathrm{g}$ powder would be a medium heat milk powder (Tab. VII) as per current nonfat dry milk heat classification (WPNI uncorrected). However, if WPNI values are expressed as mg soluble 
Table VI. Changes on heat classification of low heat SMP (A) due to protein standardization and method of expression of WPNI.

\begin{tabular}{lccccc}
\hline $\begin{array}{l}\text { Sample } \\
\text { type }\end{array}$ & $\begin{array}{c}\text { Target } \\
\text { protein }\end{array}$ & $\begin{array}{c}\text { WPNI } \\
\text { (traditional) }\end{array}$ & $\begin{array}{c}\text { Powder classification } \\
\text { based on } \\
\text { WPNI.g-1 } \text { powder }\end{array}$ & $\begin{array}{c}\text { WPNI Modified } \\
\text { WPN. } \mathrm{g}^{-1} \text { protein } \\
\left(\text { WPNI }_{\text {pcorr }}\right)\end{array}$ & $\begin{array}{c}\text { Powder classification } \\
\text { based on } \\
\text { WPNI.g- } \text { protein }^{-1}\end{array}$ \\
\hline Control & 35.1 & 6.36 & Low & 18.11 & Low \\
MPSELP34 & 34.0 & 6.04 & Low & 17.76 & Low \\
MPSELP33 & 33.0 & 5.84 & Medium & 17.69 & Low \\
MPSELP32 & 32.0 & 5.79 & Medium & 18.09 & Low \\
MPSELP31 & 31.0 & 5.54 & Medium & 17.87 & Low \\
MPSELP30 & 30.0 & 5.41 & Medium & 18.03 & Low \\
\hline
\end{tabular}

MPSELP $=$ Milk powder standardized with edible lactose powder.

WPNI $_{\text {pcorr }}=$ Protein corrected WPNI.

Table VII. Changes on heat classification of low heat SMP (B) due to protein standardization and method of expression of WPNI.

\begin{tabular}{lccccc}
\hline $\begin{array}{l}\text { Sample } \\
\text { type }\end{array}$ & $\begin{array}{c}\text { Target } \\
\text { protein }\end{array}$ & $\begin{array}{c}\text { Traditional } \\
\text { WPNI }\end{array}$ & $\begin{array}{c}\text { Powder classification } \\
\text { based on } \\
\text { WPNI.g-1 powder }\end{array}$ & $\begin{array}{c}\text { WPN.g-1 protein } \\
\left(\text { WPNI }_{\text {pcorr }}\right)\end{array}$ & $\begin{array}{c}\text { Powder classification } \\
\text { based on } \\
\text { WPNI.g-1 }\end{array}$ \\
\hline Controt & 34.3 & 6.38 & Low (control) & 18.60 & Low \\
MPSELP33 & 33.0 & 6.18 & Low & 18.72 & Low \\
MPSELP32 & 32.0 & 6.03 & Low & 18.84 & Low \\
MPSELP31 & 31.0 & 5.89 & Medium & 19.00 & Low \\
MPSELP30 & 30.0 & 5.68 & Medium & 18.93 & Low \\
MPSPP33 & 33.0 & 6.23 & Low & 18.87 & Low \\
MPSPP32 & 32.0 & 5.98 & Medium & 18.68 & Low \\
MPSPP31 & 31.0 & 5.86 & Medium & 18.90 & Low \\
MPSPP30 & 30.0 & 5.60 & Medium & 18.66 & Low \\
\hline
\end{tabular}

MPSELP $=$ Milk powder standardized with edible lactose powder.

MPSPP $=$ Milk powder standardized with permeate powder.

$\mathrm{WPNI}_{\text {pcorr }}=$ Protein corrected WPNI.

nitrogen per $\mathrm{g}$ protein $\left(\mathrm{WPNI}_{\mathrm{pcorr}}\right)$, then the WPNI value of $5.98 \mathrm{mg}$ soluble nitrogen per $\mathrm{g}$ powder at $32 \%$ protein has a

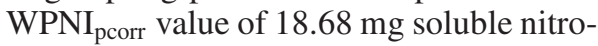
gen per $\mathrm{g}$ protein and would still be classified as low heat powder. In other words, this modification in WPNI use is to prevent misclassification of low heat powder to a medium heat powder due to protein content.

Further, medium heat or high heat powder classification will be promptly achieved more often when standardizing downwards protein content. For example, 
Scatterplot of WPN $\cdot \mathbf{g}^{-1}$ protein vs. target protein

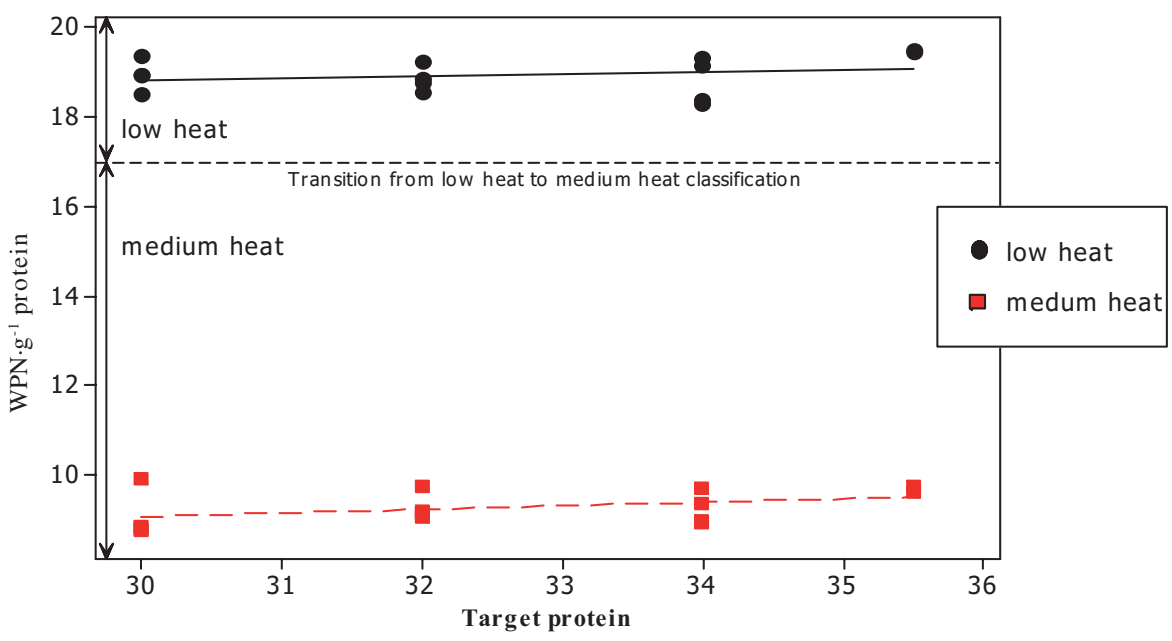

Figure 4. Effect of protein standardization on WPNI (mg of WPN. $\mathrm{g}^{-1}$ of protein) of low heat and medium heat SMP.

low heat milk powder with a WPNI value greater than or equal to $6.0 \mathrm{mg}$ nitrogen per $g$ powder, but close to medium heat classification value less than or equal to $5.9 \mathrm{mg}$ nitrogen per $\mathrm{g}$ powder can achieve medium heat classification upon its protein standardization as WPNI is positively related to protein level. Similarly, a medium heat milk powder with a WPNI value closer to $1.5 \mathrm{mg}$ of nitrogen per $\mathrm{g}$ powder can achieve high heat classification upon its protein standardization.

\section{CONCLUSIONS}

We have demonstrated that a powder with higher protein content will inherently have a greater chance of having a higher traditional WPNI value (uncorrected for protein) at equal heat treatment than a powder with lower protein content. Conversely, achieving a medium-heat classification or higher heat classification for a high protein powder can be more difficult. Specifying a WPNI value for milk powder purchases or broad heat classification without a consistent protein level may not necessarily provide the assurance in consistent performance. Re-expression of WPNI per g protein prevents erroneous heat classification due to protein content variation. This proposed modified WPNI (protein corrected) would enhance the value of this method as a means to select milk powders for their use in food applications. In light of readily available protein testing today, reexpression of WPNI to account for the potential protein content impact in heat classification may be justified. The present study suggests milk with higher protein content will have higher WPNI when everything else is same. However, we also note that WPNI was different between suppliers' at equal protein content in milk powders. Further study will be needed to explain the effects of plant processing conditions on SMP heat classification.

Acknowledgements: Authors acknowledge Dairy Management Inc., US Dairy Export Council and California Dairy Research Foundation for their financial support and the commercial dairy ingredient manufacturers for providing milk powder, lactose and permeate samples for this study. 


\section{REFERENCES}

[1] Anonymous, Standards for grades of dry milks including methods of analysis, American Dairy Products Institute, in: Bulletin 916 (1971).

[2] Anonymous, Codex standard for milk powders and cream powder, in: Codex Alimentarius 207, 1999.

[3] Anonymous, EU-27 Dairy and Products European Commission Simplifies Milk Regime 2007, in: GAIN Report, USDA Foreign Agricultural Service, 1-3.

[4] Association of Official Analytical Chemists, Official Methods of Analysis, Vol. I, 16th edn., AOAC, Gaithersburg, MD, 1995.

[5] Augustin M.A., Ingredients for recombination of dairy products, in: Proceedings of 3rd International Symposium on Recombined Milk and Milk Products, Special Issue 9902, International Dairy Federation, Brussels, Belgium (1999) 66-70.

[6] Guinee L.J., O'Kennedy B.T., Kelly P.M., Effect of milk protein standardization using different methods on the composition and yields of Cheddar cheese, J. Dairy Sci. 89 (2006) 468-482.

[7] Hardham J.F., Effect of protein standardization of milk by addition of UF milk permeate on the composition and storage stability of UHT processed milk, Aust. J. Dairy Technol. 53 (1998) 22-27.

[8] Harland H.A., Ashworth U.S., A rapid method for estimation of whey proteins as an indication of baking quality of nonfat dry milk solids, Food Res. 12 (1947) 247-251.

[9] Harland H.A., Coulter S.T., Jenness R., The effect of the various steps in the manufacture on the extent of serum protein denaturation in nonfat dry milk solids, J. Dairy Sci. 35 (1952) 363-368

[10] Harland H.A., Coulter S.T., Jenness R., Natural variation of milk serum proteins as a limitation of their use in evaluating the heat treatment of milk, J. Dairy Sci. 38 (1955) 858-869.

[11] Jensen K., Milk powders: Specifications in relation to the products to be manufactured, in: Recombination of Milk and Milk Products, International Dairy Federation, Brussels, Belgium (1990), Special Issue 9001,104-125.

[12] Kuramoto S., Jenness R., Coulter S.T., Choi R.P., Standardization of the HarlandAshworth test for whey protein nitrogen, J. Dairy Sci. 42 (1959) 28-38.

[13] Leighton F.R., Determination of whey protein index of skim milk powder, Aust. J. Dairy Technol. 17 (1962) 186-188.

[14] O'Conner F., McKenna B.M., O'Sullivan A.C., Bacteriological and whey protein denaturation aspects of heating processes used in the manufacture of low-heat skim-milk powder, Ir. J. Agric. Res. 8 (1969) 417-430.

[15] O'Sullivan A.C., O'Conner F., Aspects of heat treatment classified skim milk powder manufacture, Dairy Ind. 36 (1971) 340-344.

[16] Pearce R.J., Food functionality: success or failure for dairy based ingredients, Aust. J. Dairy Technol. 50 (1995) 15-23.

[17] Rattray W., Jelen P., Thermal stability of skim milk with protein content standardized by the addition of ultrafiltration permeates, Int. Dairy J. 6 (1996) 157-170.

[18] Rehman S.U., Farkye N.Y., Considine T., Schaffner A., Effects of standardization of whole milk with dry milk protein concentrate on the yield and ripening of reducedfat Cheddar cheese, J. Dairy Sci. 86 (2003) 1608-1615.

[19] Sanderson W.B., Seasonal variations affecting the determination of the whey protein nitrogen index of skim milk powder, N. Z. J. Dairy Sci. Technol. 5 (1970) 48-52. 